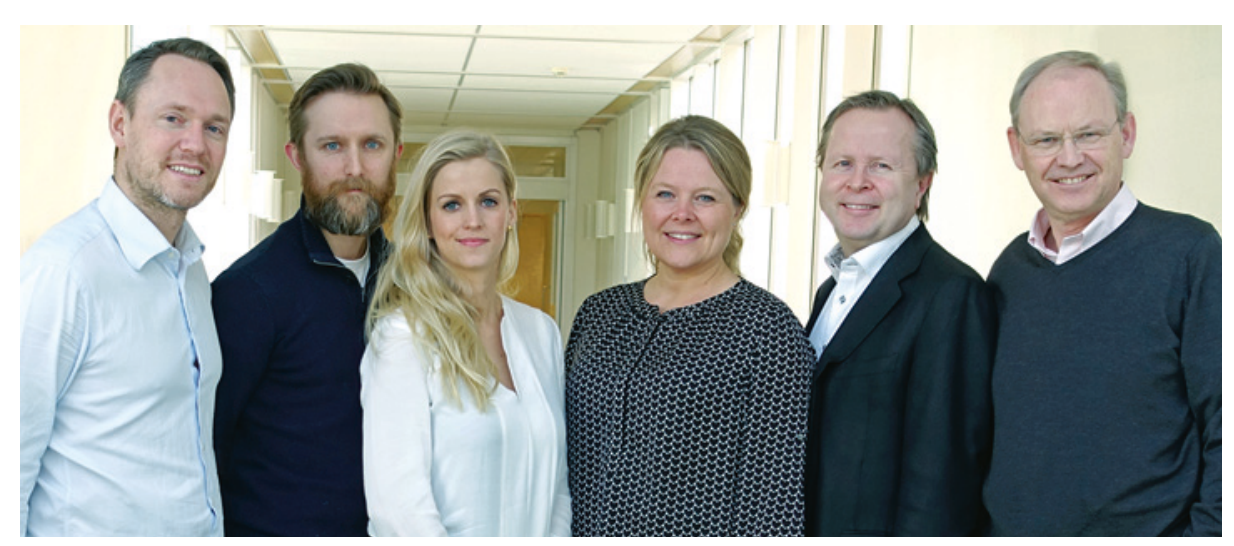

Fra venstre Helge Røsjø, William E. Louch, Anett H. Ottesen, Cathrine R. Carlson, Torbjørn Omland og Geir Christensen. Foto: Roy Trondsen, IEMF

\section{Ny prognostisk biomarkør ved hjertesvikt}

Secretoneurin er assosiert med død hos pasienter med hjertesvikt.

Virkningsmekanismen for denne biomarkøren kan representere et nytt behandlingsprinsipp.

Det finnes ingen god metode for å identifisere hjertepasienter med særlig høy risiko for hjertestans og død som følge av ventrikulære arytmier. Peptidet secretoneurin finnes i blodbanen til hjertesviktpasienter, men har det betydning for pasientens prognose og funksjonen til hjertemuskelcellene?

Norske forskere har nylig publisert en studie i tidsskriftet Journal of the American College of Cardiology (JACC), der de har undersøkt assosiasjonen mellom secretoneurinnivåer og mortalitet hos hjertesviktpasienter i tillegg til secteroneurinets funksjon (1). Artikkelen ble omtalt på lederplass i samme nummer av tidsskriftet (2).

Hos 143 pasienter innlagt i sykehus på grunn av akutt hjertesvikt og 155 pasienter med ventrikulær arytmi og hjertestans var secretoneurinnivået nær forbundet med mortaliteten. Denne assosiasjonen holdt seg også etter statistisk justering for andre risikofaktorer og etablerte biomarkører som $\mathrm{N}$-terminal pro-B-type natriuretisk peptid, høysensitivt troponin $\mathrm{T}$ og noradrenalin. I eksperimentelle modeller ble det vist at secretoneurin tas opp av hjertemuskulaturen og regulerer den intracellulære kalsiumhåndteringen $\mathrm{i}$ hjertecellene via hemming av en sentral signalvei i hjertet.

- Secretoneurin er en lovende ny biomarkør ved hjertesykdom og synes å være en kompensatorisk mekanisme som er aktivert hos pasientene med høyest risiko for ventrikulære arytmier og død, sier Helge Røsjø, som er avdelingssjef for forskning ved Medisinsk divisjon, Akershus universitetssykehus.

- Den direkte effekten av secretoneurin på hjertemuskelcellenes kalsiumhåndtering representer et lovende nytt behandlingsprinsipp. Vi har også andre studier som er i sluttfasen som vil kunne avklare secretoneurinets potensial som biomarkør i vanlig klinisk praksis, sier Røsjø.

\section{Samarbeid og patent}

Studien er utført av forskere ved Cardiothoracic Research Group ved Akershus universitetssykehus og forskere ved Institutt for eksperimentell medisinsk forskning (IEMF) ved Oslo universitetssykehus, Ullevål. Hjertesviktstudien og massespektrometri ble gjennomført ved Akershus universitetssykehus, mens de eksperimentelle studiene ble utført ved Oslo universitetssykehus.

Prosjektet har vært ledet av Helge Røsjø, med stipendiat Anett H. Ottesen som førsteforfatter. Andre sentrale medforfattere er William E. Louch, Cathrine R. Carlson, Geir Christensen og Torbjørn Omland. Prosjektet er del av Senter for hjertesviktforskning og K.G. Jebsen-senter for hjerteforskning, Universitet i Oslo. Røsjø, Christensen, Omland og M. Stridsberg fra Uppsala har patent på anvendelsen av secretoneurin som biomarkør ved hjertesykdom gjennom Universitetet i Oslo, Akershus universitetssykehus og Oslo universitetssykehus. Arbeidet er støttet økonomisk av bl.a. Nasjonalforeningen for folkehelsen, Norges forskningsråd, Helse Sør-Øst, Anders Jahres fond og K.G. Jebsen-stiftelsen.

\section{Lise Mørkved Helsingen}

Tidsskriftet

\section{Litteratur}

1. Ottesen AH, Louch WE, Carlson CR et al. Secretoneurin is a novel prognostic cardiovascular biomarker associated with cardiomyocyte calcium handling. J Am Coll Cardiol 2015; 65: 339-51.

2. Anderson ME. Will secretoneurin be the next big thing? J Am Coll Cardiol 2015; 65: 352-4.
Ordforklaringer

Biomarkør: Biologisk substans som er objektivt målbar og som reflekterer en fysiologisk/patofysiologisk prosess eller en terapeutisk intervensjon.

Statistisk multivariantanalyse: Statistiske metoder for å avklare om en variabel, for eksempel en biomarkør, er assosiert med endepunktet, uavhengig av informasjonen man får fra etablerte risikovariabler. Det er et krav at en ny biomarkør skal bidra med ny og uavhengig informasjon til etablerte risikovariabler, som høy alder, nedsatt nyrefunksjon og etablerte biomarkører, dersom den skal ha potensial for klinisk bruk

Intracellulær kalsiumhåndtering i hjerteceller: Hjertemuskelcellenes sammentrekninger (kontraksjoner) er regulert av ioneflukser over cellemembranen og inn og ut av sarkoplasmatisk retikulum. Kalsium er et sentralt ion i denne sammenheng, og frisetting av kalsium er derfor strengt regulert i hjertemuskelcellene. Ved hjertesvikt er reguleringen endret slik at mer kalsium frisettes i diastolen, noe som øker risikoen for ventrikulær arytmi og $\mathrm{d} ø \mathrm{~d}$. Secretoneurin ser ut til å motvirke diastolisk kalsiumfrisetting både i friske celler og i hjertesviktceller.
Artikkelen ble publisert i Journal of the American College of Cardiology (JACC) 3. februar 2015 og omtalt i en lederartikkel i det samme nummer av tidsskriftet 